\title{
Temperature alone does not explain patterns of Batrachochytrium dendrobatidis infections in the green frog Lithobates clamitans
}

\author{
Chelsea A. Korfel* ${ }^{*}$ Thomas E. Hetherington
}

The Ohio State University, Museum of Biological Diversity, 1315 Kinnear Rd, Columbus, OH 43212, USA

\begin{abstract}
Batrachochytrium dendrobatidis $(B d)$ is an invasive, waterborne fungal pathogen that has caused significant declines and extinctions of amphibian species worldwide. Temperature is a major factor impacting the growth and spread of $B d$, but little is known regarding the associated patterns in natural habitats. This study analyzed the temperature-associated trends, as correlated with season and microhabitat, of $B d$ prevalence and infection intensity in green frogs Lithobates clamitans in a temperate environment (central Ohio, USA). Bd was widely distributed at the study sites and found in more than half of the frogs sampled. $B d$ prevalence was significantly higher in the spring and in forested stream habitats compared to emergent wetland habitats. In contrast, $B d$ infection intensities tended to be higher in summer. Given the known temperature sensitivity of $B d$ as demonstrated in laboratory studies, these findings suggest that temperature may be an important factor determining $B d$ prevalence in green frogs at our study sites, but that factors other than temperature are more important in determining infection intensity. Our findings suggest that future monitoring of $B d$ among vulnerable species in regions experiencing seasonal temperature variation should study a range of environmental variables to better understand the dynamic relationship between $B d$ and its amphibian hosts.
\end{abstract}

KEY WORDS: Season $\cdot$ Microhabitat $\cdot$ Chytrid

\section{INTRODUCTION}

The fungal pathogen Batrachochytrium dendrobatidis $(B d)$ has been implicated in the declines and extirpations of many amphibian populations worldwide (Mendelson et al. 2006, Wake \& Vredenburg 2008, Blaustein \& Johnson 2010). Bd kills amphibians by interfering with external water exchange, thereby disrupting ion balance and leading to heart failure (Voyles et al. 2007, 2009). Temperature appears to be a major factor affecting the interaction of $B d$ with amphibian hosts (Woodhams et al. 2003, Berger et al. 2004, Piotrowski et al. 2004, Puschendorf et al. 2009, Daskin et al. 2011). $B d$ has an optimal temperature range of 17 to $23^{\circ} \mathrm{C}$ (Piotrowski et al. 2004, Voyles et al. 2011) and an operative temperature range of 4 to $28^{\circ} \mathrm{C}$ (Woodhams et al. 2003). $B d$ dies at temperatures exceeding $30^{\circ} \mathrm{C}$ (Woodhams et al. 2003). Reproduction slows at 7 to $10^{\circ} \mathrm{C}$ (Voyles et al. 2011) and stops around $4{ }^{\circ} \mathrm{C}$ (Woodhams et al. 2003), but the fungus can overwinter at temperatures approaching freezing on frogs in temperate regions (Garner et al. 2011, Savage et al. 2011). Laboratory studies on $B d$ conducted at 10 and $23^{\circ} \mathrm{C}$ have demonstrated that the fungus reproduces faster (i.e. produces more zoospores per unit time), is colonial, and is more infective at $23^{\circ} \mathrm{C}$, whereas it produces more zoospores per sporangium at $10^{\circ} \mathrm{C}$ (Woodhams et al. 2008). The pathogenity of $B d$ is more pronounced at $17^{\circ} \mathrm{C}$ than at $27^{\circ} \mathrm{C}$ (Berger et al. 2004). However, these laboratory results need to be extended to the field to understand how the fungus interacts with its amphibian hosts in natural environments. 
Large-scale $B d$-related amphibian declines correspond to ecological 'hot spots' for amphibian diversity (Lips et al. 2006, Pounds et al. 2006). The climate of these regions generally matches the optimal temperature range of the pathogen, as indicated by laboratory studies (Bustamante et al. 2005). Impacts of $B d$ appear less strong in lowland tropical areas, where temperatures often exceed the thermal tolerance of $B d$ (Blaustein \& Dobson 2006, Brem et al. 2007). However, it is unclear how both seasonal and daily variation in temperatures that are characteristic of a temperate environment may influence $B d$ pathogenicity and virulence.

Seasonal and daily temperature variation may also affect the host immune system. For example, there is evidence that $B d$ infection intensity may increase in amphibians over-wintering in hibernacula at low temperatures (Maniero \& Carey 1997, Garner et al. 2011, Savage et al. 2011, and reviewed by RollinsSmith et al. 2011), and this may facilitate spread of the fungus during the subsequent spring mating behavior, increasing the number of infected amphibians in the spring (Belden \& Harris 2007). Therefore, temperate regions present interesting challenges to both host immunity and pathogen physiology that are not found in tropical regions. The dynamics which occur between host and pathogen in a temperate region may provide important insights for global amphibian conservation.

The strong seasonal variation in the climate of many temperate environments may have significant effects on the pathogenicity and reproduction rate of $B d$. As discussed above, laboratory studies have found that temperature affects many aspects of the biology of $B d$. Among wild populations, Kinney et al. (2011) found that $27 \%$ of sampled gopher frogs Lithobates areolatus in Indiana, USA, were $B d$ positive when they entered breeding pools, whereas $46 \%$ were $B d$ positive when they left the pools. It is likely that summer temperatures in temperate climates often exceed the lethal temperature for $B d$, which may explain why cricket frogs Acris crepitans in Texas, USA, that tested positive in spring had cleared infections when temperatures increased in early summer (Gaertner et al. 2009). Other studies also indicate that as temperatures rise seasonally, $B d$ prevalence among amphibians declines (Kriger \& Hero 2007a, Duncan Pullen et al. 2010).

Microhabitats utilized by amphibians experience different temperature profiles and different seasonal temperature variations that are likely to influence $B d$ population dynamics. Kriger \& Hero (2007b) tested amphibians with different breeding strategies (e.g. terrestrial, stream, pond, etc.) to determine differences in $B d$ prevalence by habitat, and found low $B d$ prevalence in species breeding in ephemeral ponds, increased prevalence in permanent pond breeders, and the highest prevalence in permanent stream breeders. Padgett-Flohr \& Hopkins (2010) found that $B d$ persisted throughout the year in a Mediterranean climate despite monthly mean maximum temperatures only overlapping the optimal $B d$ temperature range 4 mo each year. Kinney et al. (2011) encountered $B d$ more commonly among amphibians living in deeper, cooler, permanent pools than in shallow, warmer, semi-permanent systems, and Conradie et al. (2011) found $B d$ to be more prevalent in gently flowing streams than in non-moving bodies of water or fast-moving streams. Foothill yellow-legged frogs $L$. boylii in central California had higher Bd prevalence in pool habitats with lower water temperatures (Lowe 2009). In a study of headwater streams in mountainous regions of the United States, $B d$ was detected in only $3 \%$ of 1322 individuals of 21 different species, suggesting that $B d$ is not common in headwater streams (Hossack et al. 2010.)

The overall aim of this study was to examine the dynamics of $B d$ in amphibian populations in a temperate environment and to gain insight into the potential impact of the fungus on the amphibian communities in such areas. Based on the thermal tolerance of $B d$, the influence of temperature on amphibian immune response, and the temperature profile of a temperate region, we hypothesized that infection rates and intensities would be higher when temperatures were lower and more constant than when temperatures were higher and more variable. Here, we examined the correlation between temperature (in the context of season and microhabitat) and $B d$ prevalence and infection intensity in a temperate deciduous forest region.

\section{MATERIALS AND METHODS}

\section{Study species}

Our study focused on analyzing the effect of season and habitat on $B d$ infections in green frogs Lithobates clamitans. L. clamitans is a common, diurnal, generalist species that tolerates a broad temperature gradient, inhabits a wide variety of aquatic environments, and spends considerable time both in water and on land (Martof 1952). Forzán et al. (2010) reported that $B d$ was consistently detected among $L$. clamitans in the Canadian province Prince Edward 
Island, and preliminary sampling for $B d$ in amphibian communities in central Ohio, USA, found that this species had the highest percent of infected individuals (Korfel 2012). L. clamitans are fairly tolerant of $B d$ (James et al. 2009, Schloegel et al. 2009, Kiesecker 2011 Gahl et al. 2012). L. clamitans therefore provided both an excellent estimate of $B d$ presence in the environment and the opportunity to test hypotheses regarding the impact of temperature as influenced by both habitat and season in our study area. $B d$ infection rates and intensities were studied in frogs during their entire annual period of activity in central Ohio.

\section{Sampling sites and schedule}

Sampling was conducted in protected park areas in the metropolitan area of Columbus, Ohio $\left(40^{\circ} \mathrm{N}\right.$, $83^{\circ} \mathrm{W}$, elevation range: 200 to $345 \mathrm{~m}$ above sea level). Sampling was performed for approximately $4 \mathrm{~h}$ weekly at each site (Sharon Woods, Battelle Darby, Blacklick, and Highbanks Metroparks) from spring through autumn in both 2010 (March 13 to November 11) and 2011 (April 14 to October 24) during the period of surface activity of green frogs. Two distinct habitats were sampled: emergent wetlands $(n=2)$ and closed canopy streams $(\mathrm{n}=2)$.

\section{Frog collection and swab sampling}

Juvenile and adult green frogs were captured individually in plastic bags. Sampling for $B d$ was performed on frogs while they remained confined in the plastic bags. Each frog was swabbed following the techniques of Brem et al. (2007) and Briggs \& Burgin (2003). The ventral drink patch was swabbed 10 times, and each hind thigh and foot was swabbed 5 times each (total of 30 strokes ind. ${ }^{-1}$ ). Swabs were air dried, labeled, and stored in the freezer until they were processed by quantitative PCR analysis. Frogs were also marked by toe clipping (Heyer et al. 1994) so that $B d$ infections could be followed through time. A total of 273 green frogs were sampled during the 2010 $(\mathrm{n}=33)$ and $2011(\mathrm{n}=240)$ seasons.

\section{PCR analysis and zoospore genomic equivalents}

Taqman real-time PCR analyses of swab samples were conducted at the San Diego Zoo Amphibian
Disease Laboratory and followed a modified protocol by Boyle et al. (2004). Samples were run in triplicate, and the total sample dilution of zoospores was 100. If 2 of 3 wells were positive, then the sample was determined to be positive and indicative of a low level of infection. Zoospore genomic equivalents (GEs) were calculated by averaging the results for the 3 wells and multiplying by 100 to account for the dilution of the sample. GEs were log-transformed prior to statistical analysis.

\section{Temperature data}

In 2011, temperature data loggers (HOBO pendant temperature/light data logger 64k-UA-002-64; Onset Computer Corporation, http://www.onsetcomp.com/ products/data-loggers/ua-002-64) were deployed at several of the sites we sampled in both 2010 and 2011. Two loggers were placed at each site to record ground surface and water temperatures, and each was set to collect 1 reading each hour. Terrestrial loggers were placed within $2 \mathrm{~m}$ of the aquatic habitat and covered with a thin layer of leaf litter. Aquatic data loggers were placed on the bottom of the aquatic habitat against the substrate to ensure aquatic readings regardless of changes in water level.

\section{RESULTS}

\section{Prevalence and infection intensity}

$B d$ was widely distributed in Lithobates clamitans at our field sites. $B d$ prevalence from spring through fall was statistically similar in 2010 and 2011: $51.5 \%$ infected $(\mathrm{n}=33)$ and $49.2 \%$ infected $(\mathrm{n}=240)$ respectively $(\mathrm{p}=0.854$, Fisher's exact test, 2-tailed). Infection intensities in individual frogs ranged dramatically from <1 to 190755 zoospore GEs. Mean infection intensity among infected frogs was $22250.8 \pm 46945.1$ GEs in 2010 and $678.8 \pm 6698.5$ GEs in 2011, but this difference was not statistically significant (1-way ANOVA, p < $0.001)$.

\section{Seasonal and habitat temperature data}

Ground surface and aquatic temperatures differed significantly among the different seasons and between different habitats (Table 1, Fig. 1). Mean 
Table 1. Aquatic temperatures by season for forested stream and emergent wetland habitats in 2011. Data are based on hourly readings collected during the specified season of amphibian activity: spring (April 9 - May 31); summer (June 1 August 31); autumn (September 1 - November 30); winter (December 1-30). SD: average standard deviation of daily temperatures calculated to determine the variation among temperatures recorded over a $24 \mathrm{~h}$ period

\begin{tabular}{|c|c|c|c|c|c|}
\hline \multirow[t]{2}{*}{ Season } & \multirow[t]{2}{*}{$\mathrm{n}$} & \multicolumn{4}{|c|}{ Aquatic temp. $\left({ }^{\circ} \mathrm{C}\right)$} \\
\hline & & Mean & Max. & Min. & $\mathrm{SD}$ \\
\hline \multicolumn{6}{|c|}{ Forested stream habitat } \\
\hline Spring & 1284 & 15.14 & 23.77 & 7.48 & 1.21 \\
\hline Summer & 2140 & 20.35 & 27.57 & 16.33 & 0.63 \\
\hline Autumn & 2186 & 12.20 & 19.66 & 4.73 & 0.37 \\
\hline Winter & 707 & 4.85 & 9.37 & 1.00 & 0.64 \\
\hline Annual & 6317 & 14.74 & 27.57 & 1.00 & 0.66 \\
\hline \multicolumn{6}{|c|}{ Emergent wetland habitat } \\
\hline Spring & 1284 & 17.76 & 33.95 & 6.57 & 2.48 \\
\hline Summer & 2208 & 24.72 & 33.12 & 18.33 & 0.95 \\
\hline Autumn & 2185 & 13.83 & 28.85 & 5.96 & 0.56 \\
\hline Winter & 707 & 5.70 & 7.38 & 4.00 & 0.16 \\
\hline Annual & 6317 & 17.49 & 33.95 & 4.00 & 1.03 \\
\hline
\end{tabular}

emergent aquatic temperatures were significantly higher than mean closed canopy stream aquatic temperatures (1-way ANOVA, p < 0.001) (Fig. 1a), and emergent aquatic temperatures were more variable than closed canopy stream temperatures (Fig. 1b). Water temperatures were most variable at emergent sites in the spring (average standard deviation of daily temperature, $2.48^{\circ} \mathrm{C}$ ) and least variable in closed canopy streams in the autumn (average standard deviation of daily temperature, $0.37^{\circ} \mathrm{C}$ ) (Fig. 1). The water temperature range in emergent wetlands was $28^{\circ} \mathrm{C}$ during the entire monitoring period of amphibian activity, whereas the temperature range in forested streams was $22^{\circ} \mathrm{C}$ for the same period. The amount of daily temperature variation increased from spring to summer. Variations in temperature in both 2010 and 2011 were slightly higher than averages from the past $10 \mathrm{yr}$ (NOAA 2012) during the months of amphibian activity (March to October), and 2011 received approximately $140 \%$ the normal precipitation.

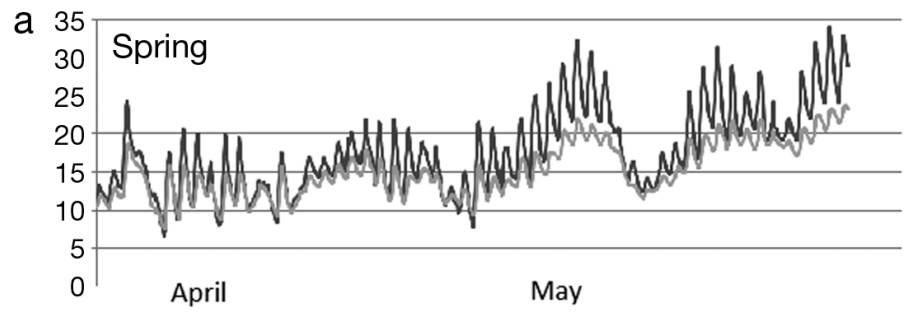

Fig. 1. (a) Seasonal aquatic temperatures and (b) temperature variations of representative forested streams and an emergent pool in 2011
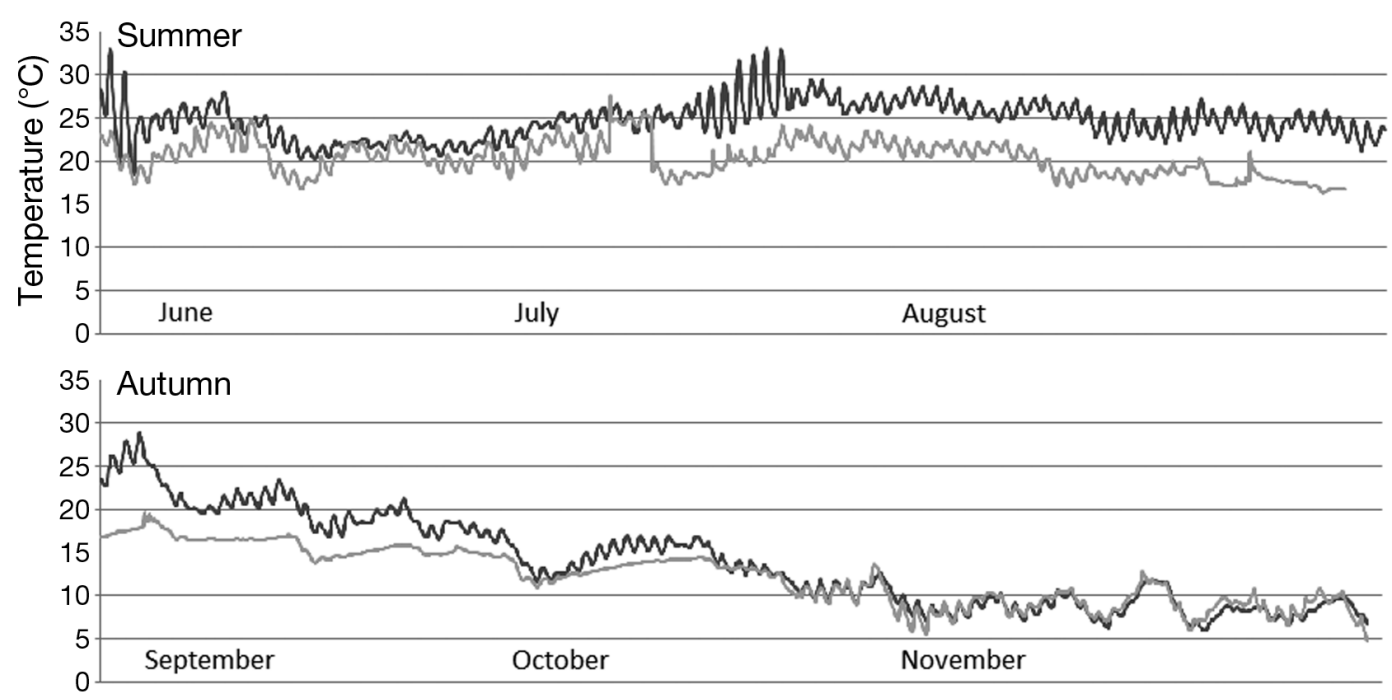

b Variation in daily temperature (SD)

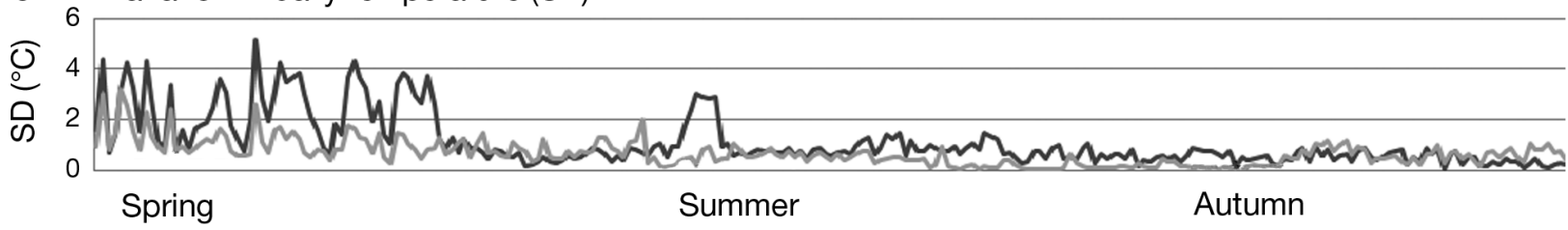




\section{Habitat differences in $B d$ prevalence and intensity}

$B d$ prevalence in L. clamitans was significantly higher in closed canopy streams $(52.6 \%$ positive, $\mathrm{n}=$ $247)$ than in emergent wetlands $(15.4 \%, \mathrm{n}=26)$ (Fisher exact test, $\mathrm{p}<0.001$ ). In contrast, infection intensities tended to be higher in emergent wetlands (18 164.0 \pm 36 206.9 GEs, $\mathrm{n}=4$ ) than in closed canopy streams $(2961.8 \pm 18$ 160.4 GEs, $\mathrm{n}=130)$.

\section{Seasonal differences in $\boldsymbol{B d}$ prevalence and intensity}

Sampling data were grouped according to the following seasons: spring (March 13 - May 19), summer (June 8 - August 29), and autumn (September 12 - November 11). Because of limited samples collected from emergent wetlands, the following analyses are limited to samples collected from forested streams (Fig. 2). $B d$ prevalence at these sites was significantly different by season (Fisher's exact test, $\mathrm{p}<0.001)$. Bd prevalence in L. clamitans peaked in spring (89\% infected, $\mathrm{n}=36)$, was lowest in the summer (38\% infected, $\mathrm{n}=104)$, and increased in autumn (55\% infected, $\mathrm{n}=107$ ). Infection intensities demonstrated a different seasonal pattern. GE values were highest among summer samples $(8239.5 \pm 31852.5$ GEs, $n=40)$, lowest in spring $(72.2 \pm 230.2$ GEs, $n=33)$, and decreased from summer to autumn $(1040.3 \pm 6455.5$ GEs, $\mathrm{n}=$ 61). However, none of the differences in $B d$ infection intensity between seasonal samples were sta-

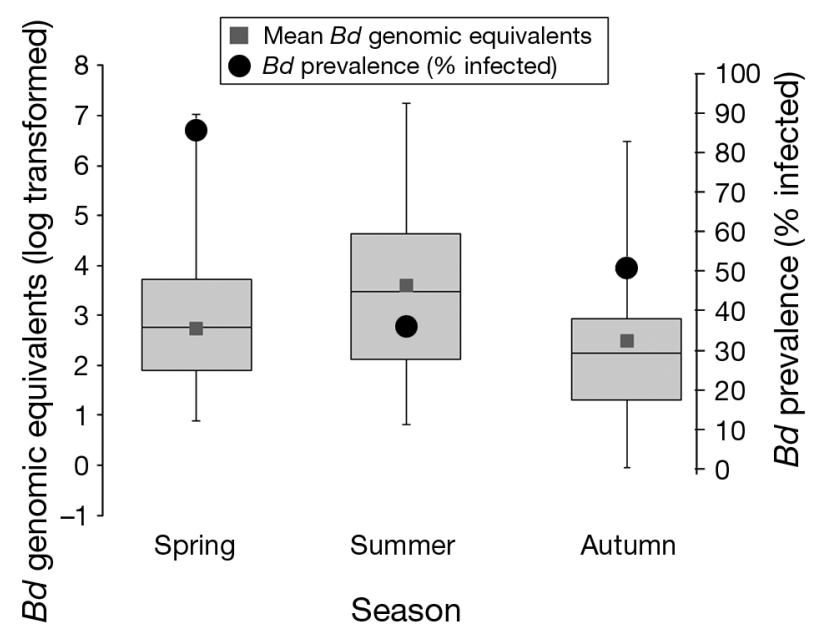

Fig. 2. Seasonal trends in Batrachochytrium dendrobatidis $(B d)$ prevalence (percent infected) and infection intensities measured in genomic equivalents of $B d$ among Lithobates clamitans in forested stream habitat. Box plots display maximum, minimum, interquartile range, and mean value tistically significant (MANOVA pairwise comparison: autumn-spring $\mathrm{p}=0.24$, autumn-summer $\mathrm{p}=$ 0.06 , spring-summer $\mathrm{p}=0.78$ ).

\section{Infection intensity and ambient temperature}

When data from all infected frogs in all seasons and from both habitats were combined, mean daily temperatures, maximum daily temperatures, and daily standard deviations of both aquatic and terrestrial temperatures were not correlated with $B d$ infection intensity (Fig. 1).

\section{Data from recaptured frogs}

Seven L. clamitans were recaptured multiple times during this study. All of the recaptured frogs carried infections in either spring or autumn, but 4 of them were infection-free in the summer. Infection intensities were low (<115 GEs, mean: 22.7 GEs) for all of the recaptured frogs.

\section{Results from dead and/or frogs displaying clinical signs of disease}

During the course of the study 5 L. clamitans were sampled that displayed signs that can be associated with chytridiomycosis. Two of these frogs tested positive for $B d$, but infection intensities were low (<1.0 GE). One of 7 frogs that likely had been dead from 1 to several days tested positive for $B d$ ( $<1.0 \mathrm{GE}$ ). We cannot say conclusively that any of these frogs were sick or died due to $B d$ infection.

\section{DISCUSSION}

\section{Prevalence and intensity of $B d$ infections in Litho- bates clamitans}

Our study documented widespread $B d$ prevalence in L. clamitans populations in central Ohio. Half of the L. clamitans sampled in this study tested positive for $B d$. The high percentage of $B d$-positive L clamitans suggests that $B d$ is present in most aquatic environments in the region, and, although L. clamitans populations appear to be robust, most individuals likely are exposed to the pathogen. High infection intensities of $B d$ zoospores, as high as $2 \times 10^{6}$ GEs, were observed in asymptomatic L. clamitans. Some 
studies have proposed that the lethal GE threshold of $10^{4}$ observed in mountain yellow-legged frogs $L$. muscosa by Vredenburg et al. (2010) may be generalizable to other frog species (Kinney et al. 2011). Our findings raise questions about the general applicability of a $10^{4}$ lethal GE threshold for anuran amphibians.

\section{Seasonal and habitat patterns of $\boldsymbol{B d}$ prevalence and infection intensity}

This study documented both seasonal and habitat differences in $B d$ prevalence and infection intensities in L. clamitans populations in central Ohio. Statistically significant differences in seasonal patterns of $B d$ prevalence were observed in closed canopy stream habitats that afforded a large sample size. In these forested streams the lowest prevalence occurred in the summer and higher prevalence rates were found in the spring and autumn. There were no significant differences observed in seasonal patterns of infection intensities, although there was a trend of increased infection intensities in summer. $B d$ prevalence and infection intensity therefore showed different seasonal patterns. The 2 habitat types sampled in this study (closed canopy streams and emergent wetlands) also showed different patterns of $B d$ prevalence and infection intensity. $B d$ prevalence was significantly higher in frogs collected from closed canopy streams. In contrast, infection intensities tended to be higher among frogs in emergent wetlands, although the difference was not statistically significant.

The different seasonal and habitat patterns observed for $B d$ prevalence and $B d$ infection intensity were unexpected. Based on the known temperature sensitivity of $B d$, we expected both prevalence and infection intensity to be strongly tied to seasonal and habitat temperature trends and to be higher in lower temperature habitats and at lower temperature times of the year. The higher prevalence of $B d$ during the lower temperature spring and in the lower temperature closed canopy stream habitat supported this hypothesis. Forrest \& Schlaepfer (2011) found 75 to $100 \% B d$ prevalence among amphibians in Arizona, USA, in water at temperatures $<15^{\circ} \mathrm{C}$ (similar to findings in spring and autumn in our study) and much lower prevalence $(<10 \%)$ in water at temperatures $>30^{\circ} \mathrm{C}$ (similar to summer and emergent habitat findings in our study). Other studies have found that $B d$ is more prevalent in more shaded, lower temperature habitat in the temperate USA (Raffel 2010) and in gently flowing streams compared to non-flowing water in African grasslands (Conradie et al. 2011). It is likely that shaded habitats and flowing water maintain lower temperatures more suitable for $B d$ survival (Raffel 2010).

In contrast to $B d$ prevalence, the seasonal and habitat patterns of $B d$ infection intensity were unexpected. Although no statistically significant relationship was found, infection intensities tended to be higher (rather than lower) in the summer months and in emergent wetland sites where temperatures were higher. Combined analysis of the entire sample of infected frogs from all seasons and both habitat types showed no relationship between infection intensity and daily mean, maximum, or standard deviation of sampling site temperatures. $B d$ infection intensity therefore did not show the negative relationship with ambient temperature associated with rates of $B d$ prevalence. Certain studies suggest that temperature should influence $B d$ infection intensity. For example, Maniero \& Carey (1997) suggest that $B d$ infections are likely to increase when amphibian immune function is reduced at lower and more variable temperatures. Longo et al. (2010) report season as a strong predictor of both $B d$ prevalence and infection intensity among direct-developing Eleutherodactylus coqui and E. portoricensis in a tropical system. However, seasonal variation in tropical systems typically emphasizes differences in precipitation rather than temperature, so ambient temperature may not have been the dominant factor affecting $B d$-host dynamics in this study. One possible explanation for our findings among green frogs in Ohio is that host immunity increases as temperature increases, so frogs tolerate higher $B d$ loads before succumbing to infection. Therefore, less $B d$-associated mortality at higher rates of infection may lead to a higher mean infection burden in summer months. It is also possible that different environmental and/or organismal factors may contribute to seasonal and habitat patterns of $B d$ prevalence and $B d$ infection intensity in green frog populations in temperate central Ohio.

\section{Potential factors behind seasonal and habitat patterns of $\boldsymbol{B d}$ prevalence and infection intensity}

Temperature is thought to be a major factor determining $B d$ pathogenicity and amphibian host susceptibility to $B d$ (Woodhams et al. 2003, Berger et al. 2004, Piotrowski et al. 2004, Puschendorf et al. 2009, Daskin et al. 2011). However, in our study, only $B d$ prevalence, and not $B d$ infection intensity, was corre- 
lated with temperature. It is possible to speculate on the reasons for the different relationships of prevalence and infection intensity to temperature in our study. As mentioned above, Maniero \& Carey (1997) suggest that $B d$ infections are likely to increase when amphibian immune function is reduced at lower and more variable temperatures. $B d$ prevalence is also likely to increase at relatively low temperatures. Woodhams et al. (2008) demonstrated that Bd zoospores live longer in lower temperature water and that $B d$ responds to cold shocks by temporarily increasing zoospore production. $B d$ reproduces faster at higher temperatures, zoospores were faster to encyst at higher temperatures (ultimately resulting in increased infectivity at $23^{\circ} \mathrm{C}$ compared to $10^{\circ} \mathrm{C}$ ), and zoospores died at temperatures $>30^{\circ} \mathrm{C}$ (Woodhams et al. 2008). Voyles et al. (2012) found that despite lower population growth rates at $4^{\circ} \mathrm{C}$ compared to $23^{\circ} \mathrm{C}, B d$ activity rates were increased, which may ultimately result in higher zoospore encounter rates for amphibians at lower temperatures. According to these findings, we would expect $B d$ infections to be severe at lower temperatures when amphibian host immune systems are suppressed, the likelihood of encountering zoospores is elevated, and when $B d$ biology favors pathogenicity. We would expect $B d$ infections to be mild when temperatures are $>30^{\circ} \mathrm{C}$ and overall $B d$ prevalence is low. However, results from our fieldwork indicate that infection intensity was not related to temperature and, in fact, tended to be highest during higher temperatures when $B d$ prevalence was lowest.

It is possible that high temperatures characteristic of emergent pools and summer months in central Ohio may favor re-encystment (increasing infection intensity on a single frog) but reduce the chance of $B d$ zoospores infecting a new host (decreasing prevalence within the population). The higher infection intensities observed in summer months may be explained by direct temperature effects on the fungus (i.e. facilitated re-encystment) but most likely are related to differential susceptibility among frogs in a population. Other stressors in higher temperature environments (e.g. parasites, etc.) may make certain individuals less capable of suppressing $B d$ infections. We suggest that future studies of $B d$ pathogenicity consider stress at the individual level.

\section{CONSERVATION IMPLICATION}

Although $L$. clamitans appears to be highly resistant to $B d$, the seasonal and habitat patterns of the $B d$ dynamics observed in this study may have implications for other more susceptible amphibian species. High infection prevalence in spring and high infection intensities in summer are of particular concern. Infection intensity likely involves a complex synergy of factors that include environmental variables, host immune system capabilities, and the timing of exposure. Frogs with high-intensity infections did not exhibit any symptoms of disease; however, none of these frogs were recaptured to determine survival. A small number of frogs with low-intensity infections were recaptured throughout the seasons and provide evidence that this species can gain and clear low-intensity infections. Our results suggest highintensity infections may be of greater concern than widespread prevalence because it is high-intensity infections that likely result in mortality. Species more susceptible to $B d$ than $L$. clamitans that experience similar seasonal patterns of infection may display higher mortality.

Based on our findings, future monitoring for $B d$ presence in temperate areas such as Ohio should focus on springtime when $B d$ is most common. Amphibians emerging from overwintering sites may have reduced immune function in lower and fluctuating temperatures (Garner et al. 2011), as well as skinto-skin contact during breeding events combined with optimal temperatures for $B d$ reproduction and decreased mortality, may exacerbate $B d$ spread. In contrast, monitoring for $B d$-induced mortality, which likely occurs when $B d$ infection intensities reach a species-specific threshold, is dependent on factors other than temperature alone.

Acknowledgements. This work was funded by grants received from the Columbus Zoo and Aquarium, the Ohio State University, the National Science Foundation (Graduate Research Fellowship), and the Ohio Division of Wildlife. We thank Marylouise Bohannon, Jessica Dopkiss, and Brad Lawson for their help with the fieldwork. We thank the UALR Gifford laboratory for peer review and contributions to this manuscript. We also recognize the Columbus MetroParks and the San Diego Amphibian Disease Laboratory for their cooperation in conducting this research.

\section{LITERATURE CITED}

Belden LK, Harris RN (2007) Infectious diseases in wildlife: the community ecology context. Front Ecol Environ 5: 533-539

> Berger L, Speare R, Hines HB, Marantelli G and others (2004) Effect of season and temperature on mortality on amphibians due to chytridiomycosis. Aust Vet J 82:433-439

Blaustein AR, Dobson A (2006) Extinctions: a message from the frogs. Nature 439:143-144 
Blaustein AR, Johnson PTJ (2010) Conservation biology: when an infection turns lethal. Nature 465:881-882

Boyle DG, Boyle DB, Olsen V, Morgan JAT, Hyatt AD (2004) Rapid quantitative detection of chytridiomycosis (Batrachochytrium dendrobatidis) in amphibian samples using real-time Taqman PCR assay. Dis Aquat Org 60:141-148

Brem F, Mendelson JR III, Lips KR (2007) Field sampling protocol for Batrachochytrium dendrobatidis from living amphibians using alcohol preserved swabs, Version 1.0 (18 July 2007). Conservation International, Arlington, VA. Available at: www.amphibians.org.

Briggs C, Burgin S (2003) Rapid technique to detect chytrid infection in adult frogs. Herpetol Rev 34:124-126

> Bustamante MR, Ron SR, Coloma LA (2005) Cambios en la diversidad en siete communidad de anuros en los Andes de Ecuador. Biotropica 37:180-189

> Conradie W, Weldon C, Smith KG, Du Preez LH (2011) Seasonal pattern of chytridiomycosis in common river frog (Amietia angolensis) tadpoles in the South African grassland biome. Afr Zool 46:95-102

> Daskin JH, Alford RA, Puschendorf R (2011) Short-term exposure to warm microhabitats could explain amphibian persistence with Batrachochytrium dendrobatidis. PLoS ONE 6:e26215

Forrest MJ, Schlaepfer MA (2011) Nothing a hot bath won't cure: infection rates of amphibian chytrid fungus correlate negatively with water temperature under natural field settings. PLoS ONE 6:e28444

Forzán MJ, Vanderstichel B, Hogan NS, Teather K, Wood J (2010) Prevalence of Batrachochytrium dendrobatidis in three species of wild frogs on Prince Edward Island, Canada. Dis Aquat Org 91:91-96

Gaertner JP, Gaston MA, Spontak D, Forstner MRJ, Hahn D (2009) Seasonal variation on the detection of Batrachochytrium dendrobatidis in a Texas population of Blanchard's cricket frog (Acris crepitans blanchardi). Herpetol Rev 40:184-187

> Gahl MK, Longcore JE, Houlahan JE (2012) Varying responses of North American amphibians to the chytrid pathogen Batrachochytrium dendrobatidis. Conserv Biol 26:135-141

Garner TWJ, Rowcliffe JM, Fisher MC (2011) Climate change, chytridiomycosis or condition: an experimental test of amphibian survival. Glob Change Biol 17: 667-675

Heyer WR, Donnelly MA, McDiarmid RW, Hayek LAC, Foster MS (1994) Measuring and monitoring biological diversity: standard methods for amphibians. Smithsonian Books, Washington, DC

> Hossack BR, Adams MJ, Campbell-Grant EH, Pearl CA and others (2010) Low prevalence of chytrid fungus (Batrachochytrium dendrobatidis) in amphibians of US headwater streams. J Herpetol 44:253-260

James TY, Litvintseva AP, Vilgalys R, Morgan JAT and others (2009) Rapid global expansion of the fungal disease chytridiomycosis into declining and healthy amphibian populations. PLoS Pathog 5:e1000458

Kiesecker JM (2011) Global stressors and the global decline of amphibians: tipping the stress immunocompetency axis. Ecol Res 26:897-908

> Kinney VC, Heemeyer JL, Pessier AP, Lannoo MJ (2011) Seasonal pattern of Batrachochytrium dendrobatidis infection and mortality in Lithobates areolatus: affirmation of Vredenburg's '10,000 Zoospore Rule.'. PLoS ONE 6:e16708
Korfel CA (2012) Distribution and environmental correlates between amphibians and the fungal pathogen, Batrachochytrium dendrobatidis. PhD dissertation, The Ohio State University, Columbus, $\mathrm{OH}$

Kriger KM, Hero JM (2007a) Large scale seasonal variation in the prevalence and severity of chytridiomycosis. J Zool 271:352-359

Kriger KM, Hero JM (2007b) The chytrid fungus Batrachochytrium dendrobatidis is non-randomly distributed across amphibian breeding habitats. Divers Distrib 13: 781-788

Lips KR, Brem F, Brenes R, Reeve JD and others (2006) Emerging infectious disease and the loss of biodiversity in a neotropical amphibian community. Proc Natl Acad Sci USA 103:3165-3170

Longo AV, Burrowes PA, Joglar RL (2010) Seasonality of Batrachochytrium dendrobatidis infection in direct developing frogs suggests a mechanism for persistence. Dis Aquat Org 92:253-260

Lowe J (2009) Amphibian chytrid (Batrachochytrium dendrobatidis) in post-metamorphic Rana boylii in the inner coast ranges on central California. Herpetol Rev 40: 180-182

> Maniero GD, Carey C (1997) Changes in selected aspects of immune function in the leopard frog, Rana pipiens, associated with exposure to cold. J Comp Physiol B 167: 256-263

> Martof BS (1952) Early transformation if the greenfrog, Rana clamitans latreille. Copeia 1952:115-116

> Mendelson JR, Lips KR, Gagliardo RW, Rabb GB and others (2006) Biodiversity - confronting amphibian declines and extinctions. Science 313:48

NOAA (National Oceanic and Atmospheric Administration) (2012) Climate data for Columbus, Ohio. Available at: www.erh.noaa.gov (accessed 12 June 2012)

Padgett-Flohr GE, Hopkins RL III (2010) Landscape epidemiology of Batrachochytrium dendrobatidis in central California. Ecography 33(4):688-697

Piotrowski JS, Annis SA, Longcore JE (2004) Physiology of Batrachochytrium dendrobatidis, a chytrid pathogen of amphibians. Mycologia 96:9-15

> Pounds JA, Bustamante MA, Coloma LA, Consuegra JA and others (2006) Widespread amphibian extinctions from epidemic disease driven by global warming. Nature 439: $161-167$

Pullen KD, Best AM, Ware JL (2010) Amphibian pathogen Batrachochytrium dendrobatidis prevalence is correlated with season and not urbanization in central Virginia. Dis Aquat Org 91:9-16

Puschendorf R, Carnaval AC, VanDerWal J, Zumbado-Ulate H, Chaves G, Bolanos F, Alford RA (2009) Distribution models for the amphibian chytrid Batrachochytrium dendrobatidis in Costa Rica: proposing climatic refuges as a conservation tool. Divers Distrib 15:401-408

> Raffel TR (2010) What drives chytrid infections in newt populations? Substrate, temperature, shade. EcoHealth 7 : 526-536

Rollins-Smith LA, Ramsey JP, Pask JD, Reinert LK, Woodhams DC (2011) Amphibian immune defenses against chytridiomycosis: impacts of changing environments. Integr Comp Biol 51:552-562

Savage AE, Sredl MJ, Zamudio KR (2011) Disease dynamics vary spatially and temporally in a North American amphibian. Biol Conserv 144:1910-1915

Schloegel LM, Picco AM, Kilpatrick AM, Davies AJ, Hyatt 
AD, Daszak P (2009) Magnitude of the US trade in amphibians and presence of Batrachochytrium dendrobatidis and ranavirus infection in imported North American bullfrogs (Rana catesbeiana). Biol Conserv 142: 1420-1426

Voyles J, Berger L, Young S, Speare R, Webb R, Warner J, Rudd D, Campbell R, Skerratt LF (2007) Electrolyte depletion and osmotic imbalance in amphibians with chytridiomycosis. Dis Aquat Org 77:113-118

> Voyles J, Young S, Berger L, Campbell C and others (2009) Pathogenesis of chytridiomycosis, a cause of catastrophic amphibian declines. Science 326:582-585

Voyles J, Rosenblum EB, Berger L (2011) Interactions between Batrachochytrium dendrobatidis and its amphibian host: a review of pathogenesis and immunity. Microbes Infect 13:25-32

Voyles J, Johnson LR, Briggs CJ, Cashins SD, Alford RA, Berger L, Skerratt LF, Speare R, Rosenblum EB (2012)

Editorial responsibility: Lee Skerratt,

Townsville, Queensland, Australia
Temperature alters reproductive life history patterns on Batrachochytrium dendrobatidis, a lethal pathogen associated with the global loss of amphibians. Ecol Evolut 2: 2241-2248

- Vredenburg VT, Knapp RA, Tunstall TS, Briggs CJ (2010) Dynamics of an emerging disease drive large-scale amphibian population extinctions. Proc Natl Acad Sci USA 107:9689-9694

Wake DB, Vredenburg VT (2008) Are we in the midst of the sixth mass extinction? A view from the world of amphibians. Proc Natl Acad Sci USA 105:11466-11473

> Woodhams DC, Alford RA, Marantelli G (2003) Emerging disease of amphibians cured by elevated body temperature. Dis Aquat Org 55:65-67

> Woodhams DC, Alford RA, Briggs CJ, Johnson M, RollinsSmith LA (2008) Life history trade-offs influence disease in changing climates: strategies of an amphibian pathogen. Ecology 89:1627-1639

Submitted: August 13, 2013; Accepted: April 1, 2014 Proofs received from author(s): June 12, 2014 